\title{
HYDROMETALLURGICAL PROCESSING OF NICKEL LATERITIC ORES
}

\author{
Srećko R. Stopića ${ }^{a}$ Bernd G. Friedrich ${ }^{b}$ \\ RWTH Aachen University, Faculty of Georesources \\ and Materials Engineering, \\ IME Process Metallurgy and Metal Recycling, Aachen, Germany \\ a e-mail: sstopic@ime-aachen.de, \\ ORCID iD: ibhttp://orcid.org/0000-0002-1752-5378 \\ b e-mail: bfriedrich@ime-aachen.de, \\ ORCID iD: (iohttp://orcid.org/0000-0002-2934-2034,
}

DOI: $10.5937 /$ vojtehg64-10592

FIELD: Chemical Technology

ARTICLE TYPE: Review Paper

ARTICLE LANGUAGE: English

\section{Summary:}

Nickel production is a very important activity for the European Union because nickel is a unique constituent of stainless steel. Europe has lateritic (oxidic) ore deposits along a very well-known belt starting from the Alps and ending to the Himalayas. The lateritic belt passes through western Balkans and Greece and continues through Turkey to Asia. The known lateritic deposits in Serbia are located in three different areas called: Zapadna Morava (Rudjinci, Veluce, Ba), Sumadija (Lipovac, Kolarevici, Bucje) and Mokra Gora, which have many natural resources such as forests, rivers, etc. Therefore, it is very important to understand and show hydrometallurgical treatments of lateritic ores via mining and metallurgy in different parts of the world. In this paper, several exploitation scenarios for hydrometallurgical treatment and benefication of lateritic ores will be shown: Direct Nickel Process, Ravensthorpe and Murrin Murrin in Australia and Meta Cobalt Nickel in Turkey.

Key words: nickel, cobalt, lateritic ore, hydrometallurgy, autoclave. 


\section{Introduction}

Nickel is a naturally occurring, silvery-white metallic element widely used in over 300,000 products for catalysis, consumer, industrial, military, transport, aerospace, marine and architectural applications. Nickel has been used since ancient times. Because of its resistance to corrosion, nickel has been occasionally used historically as a substitute for decorative silver. Pure nickel was extracted by Axel Cronstedt from the ore niccolite (nickel arsenide, NiAs) in 1751. Because of its presence in copper ores, this element got its name from the German word 'kupfernickel' meaning Devil's copper. It is the fifth most common element on earth and occurs extensively in the earth's crust. In this work, different hydrometallurgical processes for the treatment of nickel laterite ores will be presented. Nickel is not a cumulative toxicant. Some people may show an allergy sensibility to nickel, affecting their skin (about 5 to $10 \%$ in Europe).

As a result of high nickel production costs associated with traditional pyrometallurgical techniques and the depletion of high-grade sulfide ores, a renewed interest has developed concerning the production of nickel and cobalt by high pressure acid leaching (HPAL) of nickel laterites. More than one third of the world's nickel is nowadays produced from laterite ores (Bergmann, 2003, pp.127-138). Laterites account for two thirds of the world's nickel resources. It is therefore likely that increasing amounts of nickel will be produced from laterites. Since laterite type ores naturally occur close to the surface, economical open pit mining techniques are employed to recover the ore after the removal of the overburden (Whittington \& Muir, 2000, pp.527-600). The laterite ore consists of fresh saprolite, limonite and nontronite. These ores represent various layers in the laterite bedrock. Limonite consists mainly of goethite, a hydrated iron oxide such as $\mathrm{FeO}(\mathrm{OH}), \mathrm{HFeO} 2$, or $\mathrm{Fe} 2 \mathrm{O} 3 \cdot \mathrm{H} 2 \mathrm{O}$. This continues to a nontronite rich zone. Saprolite is the next layer, which is distinguished from its rich magnesium silicate content. The chemical analyses of a few chosen ores are shown in Table 1 (Stopić, 2004, pp.257-266)

Table 1 - ICP Analyses of the Average Content of Laterite Ore from "Rudjinci", Serbia and from "Silcrete", Australia

Таблица 1 - ІСР Анализ среднего объема латеритных руд в «Руджинцы», Сербия и в "Silcrete", Австралия

Tabela 1 - ICP analize prosečnog sadržaja lateritnih ruda nikla u „Ruđinci“ (Srbija) i „Sllcrete“ (Australija)

\begin{tabular}{ccc}
\hline Element & "Rudjinci", Serbia (wt \%) & "Silcrete", Australia (wt \%) \\
\hline $\mathrm{Si}$ & 25.33 & 17.40 \\
$\mathrm{Fe}$ & 14.90 & 26.42 \\
$\mathrm{Al}$ & 2.12 & 4.16 \\
$\mathrm{Cr}$ & 1.30 & 0.67 \\
$\mathrm{Ni}$ & 1.13 & 0.78 \\
$\mathrm{Co}$ & 0.05 & 0.05 \\
$\mathrm{Mg}$ & 3.22 & 1.70 \\
$\mathrm{Mn}$ & 0.37 & 0.25 \\
$\mathrm{Na}$ & 0.04 & 0.04 \\
$\mathrm{~K}$ & 0.04 & 0.05 \\
\hline
\end{tabular}


As shown in Table 1, the nickel content in oxidic ores amounts to between 0.78 and 1.13 wt. \%. The main accompanying elements are silicium, iron, magnesium and aluminium. The above mentioned ores were investigated under high pressure conditions in an autoclave. The comparative analysis of different minerals shows a different content of important elements, what is very important for the choice of leaching.

Table 2 - Chemical composition of nontronite and limonite Таблица 2 - Химический состав нонтронита и лимонита Tabela 2 - Hemijski sastav nontronita i limonita

\begin{tabular}{|l|c|c|c|c|c|}
\hline$[\%]$ & $\mathrm{Fe}$ & $\mathrm{Al}$ & $\mathrm{MgO}$ & $\mathrm{Ni}$ & $\mathrm{Co}$ \\
\hline Nontronite & $10-30$ & $8-10$ & $5-15$ & $0.6-2$ & $0.02-0.1$ \\
\hline Limonite & $40-50$ & $7-9$ & $0.5-5$ & $0.8-1.5$ & $0.1-0.2$ \\
\hline
\end{tabular}

\section{Leaching Methods}

In hydrometalurgical processes, three different methods are usually used: tank leaching, heap leaching and high pressure acidic leaching HPAL. Tank leaching uses a stirrer and reagents to get the reaction started. An overflow leads the suspension to another tank, where the pregnant solution and the slurry are separated by a solid/liquid separation process.
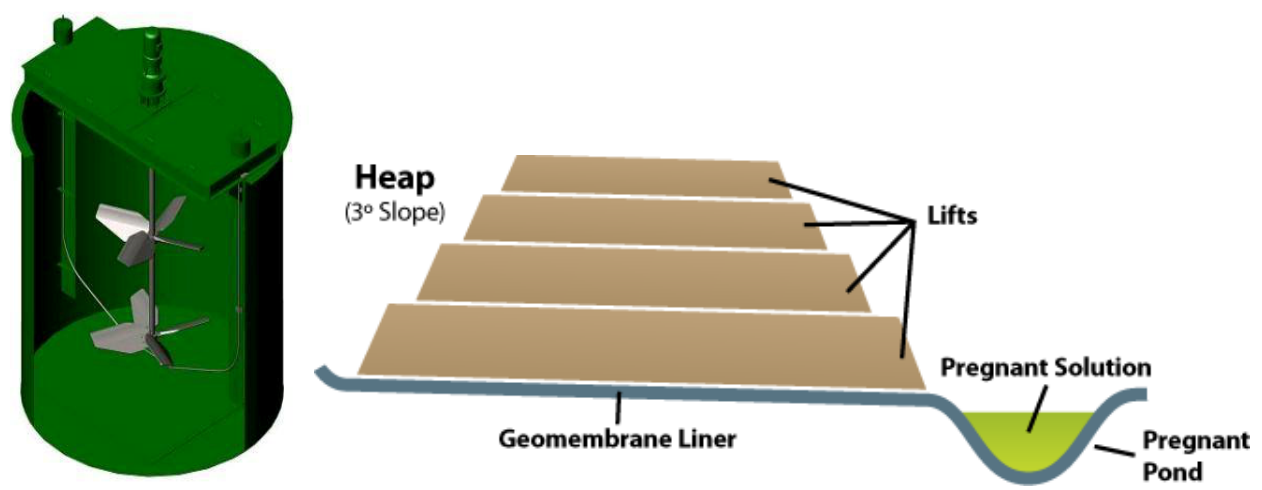

Figure 1 - Leaching under atmospheric pressure: tank (left) and heap (right) Puc. 1 - Промывка при атмосферном давлении: в баке (слева) и в куче (справа) Slika 1 - Luženje pri atmosferskom pritisku: u tanku (levo) i na gomilama (desno)

Heap leaching is a very slow process, where the acid is spread dropwise on a heap, slowly pouring to the bottom. Superiadi had some remarks about the following heap leaching processes (Superiadi, 2008, pp.25). During this reaction time, the used acid reacts with the minerals.

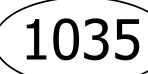


Table 3 - The most known heap leaching processes

Таблица 3 - Самые распространенные методы промывки руд в куче Tabela 3 - Najpoznatiji procesi luženja na gomilama

\begin{tabular}{|l|l|l|l|}
\hline Project & Owner & Country & Remarks \\
\hline Caldag & $\begin{array}{l}\text { European } \\
\text { Nickel }\end{array}$ & Turkey & $\begin{array}{l}\text { First Heap Leach } \\
\text { project }\end{array}$ \\
\hline Ravensthorpe & BHP-B & Australia & Part of flow sheet \\
\hline Murrin-Murrin & Minara & Australia & Expansion of project \\
\hline Piaui & Vale & Brazil & $\begin{array}{l}\text { Being fast-tracked for } \\
\text { production }\end{array}$ \\
\hline
\end{tabular}

Leaching under high pressure was performed in special devices (autoclaves). Slurred, crushed ore from the mine is conveyed to the processing plant to be pressure leached with sulphuric acid. The High Pressure Acid Leaching HPAL area receives the slurred feed, heats it up to $225-270^{\circ} \mathrm{C}$ and mixes it with hot concentrated sulphuric acid inside four titanium-lined autoclaves. Nickel and cobalt are dissolved into the solution.

$$
\begin{aligned}
& \mathrm{NiO}+\mathrm{H}_{2} \mathrm{SO}_{4} \rightarrow \mathrm{NiSO}_{4}+\mathrm{H}_{2} \mathrm{O} \\
& \mathrm{CoO}+\mathrm{H}_{2} \mathrm{SO}_{4} \rightarrow \mathrm{CoSO}_{4}+\mathrm{H}_{2} \mathrm{O}
\end{aligned}
$$

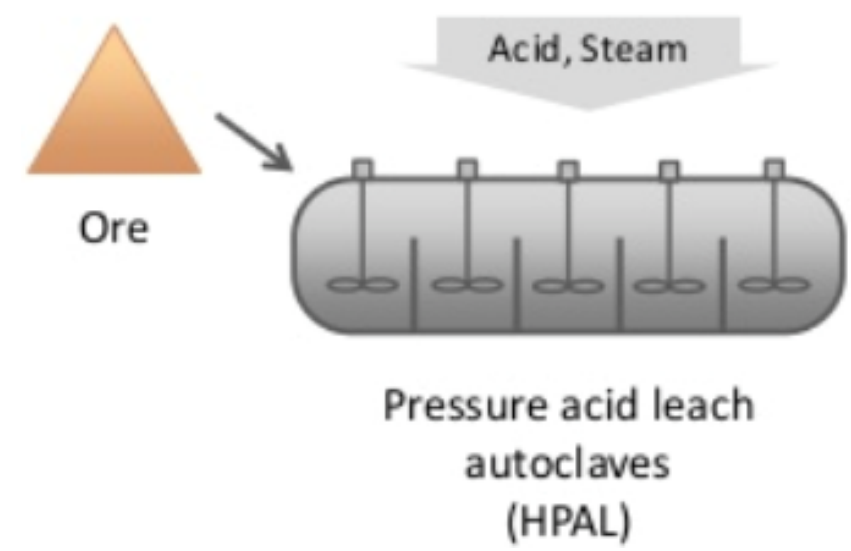

Figure 2 - High Pressure Leaching of nickel lateritic ores HPAL

Puc. 2 - Промывка латеритных руд под высоким давлением в автоклаве Slika 2 - Luženje pri visokom pritisku u autoklavu 
The hydrometallurgical processing of nickel lateritic ores begins with an acidic solution (Dry \&Haris, 2012, pp.20-35). The dominant acid so far has been sulphuric acid, but research work has been published on the process using hydrochloric acid or nitric acid. Sulphuric acid, hydrochloric acid, and nitric acid are the three major mineral acids for the leaching of laterites. The comparative analysis has shown that both the chloride and the nitrate circuits examined have appreciably lower operating costs than the sulphate circuits. The dissolution kinetics of nickel lateritic ore in an aqueous acid solution of three metabolic acids, i. e. citric acid, oxalic acid and acetic acid was investigated in a batch reactor individually (Sahu et al., 2011, pp.251-258). The percentage of nickel leaching for different acids at the time intervals of 40,80 and 120 hours at a concentration of $1 \mathrm{M}$ was studied. Oxalic acid was the most efficient leaching agent compared to the other two used acids. The maximum leaching efficiency was about $30 \%$ under the above mentioned conditions. Superiadi has performed a comparative analysis of different leaching processes for lateritic ores.

Table 4 - Comparative analysis of different leaching processes for lateritic ores Таблица 4 - Сопоставительный анализ различных методов промывки латеритных руд Tabela 4 - Uporedna analiza raznih procesa luženja za lateritne rude

\begin{tabular}{|c|c|c|c|c|}
\hline Process & $\begin{array}{c}\text { Main } \\
\text { Feed }\end{array}$ & $\begin{array}{c}\text { Electricity } \\
\text { Require }\end{array}$ & $\begin{array}{c}\text { Capital } \\
\text { Cost }\end{array}$ & $\begin{array}{c}\text { Operating } \\
\text { Cost }\end{array}$ \\
\hline HPAL & Limonite & Low & High & Low \\
\hline Caron & Saprolite & Moderate & Very High & High \\
\hline $\begin{array}{c}\text { Heap } \\
\text { Leach }\end{array}$ & Limonite & Very Low & Moderate & Low \\
\hline $\begin{array}{c}\text { Chloride } \\
\text { Leach }\end{array}$ & $\begin{array}{c}\text { Limonite } \\
\text { Saprolite }\end{array}$ & Moderate & High & Low \\
\hline
\end{tabular}

The Caron process contains a thermal pretreatment and the final ammoniacal leaching. Therefore, this process needs more capital costs. This process is not a subject of this paper. HPAL, Heap Leach and Chloride leach have low electricity request and operating costs. The high pressure leaching process is considered in our previous publication (Stopić, 2011, pp.29-44). One detailed analysis of different 
deposits confirms an advantage of the used HPAL-processes regarding the maximum leaching efficiency of nickel and cobalt (approx. above $90 \%$ ).

Table 5 - Comparative analysis of the leaching efficiency of $\mathrm{Ni}$ and Co Таблица 5 - Сопоставительный анализ эффективности промывки никеля и кобальта Tabela 5 - Uporedna analiza stepena luženja za nikal i kobalt

\begin{tabular}{llcccc} 
Process & Ore Type & $\begin{array}{c}\text { Acid Req. } \\
\text { (kg/tonne ore) }\end{array}$ & Leach Time & $\begin{array}{c}\text { Ni Rec. } \\
(\%)\end{array}$ & $\begin{array}{c}\text { Co Rec. } \\
(\%)\end{array}$ \\
\hline $\begin{array}{l}\text { Tank } \\
\text { Leaching }\end{array}$ & Nontronite & 856 & $5 \mathrm{~h}$ & 92.8 & 77.0 \\
\hline $\begin{array}{l}\text { Heap } \\
\text { Leaching }\end{array}$ & Limonite & 907 & $24 \mathrm{~h}$ & 85.2 & 87.0 \\
& Lontronite & 462 & 144 days & 83.9 & 55.2 \\
\hline \multirow{2}{*}{ HPAL } & Nontronite & 560 & 534 days & 65.5 & 57.1 \\
& Limonite & 536 & $90 \mathrm{~min}$ & 98.1 & 94.4 \\
& Blend (Pilot Scale) & $\mathbf{3 1 5}$ & $\mathbf{6 0} \mathbf{~} \mathbf{m i n}$ & $\mathbf{9 0 . 0}$ & $\mathbf{9 7 . 0}$ \\
\hline
\end{tabular}

The study aims to compare three different hydrometallurgical processes for the treatment of nickel lateritic ores: Direct Nickel, Meta and Minara HPAL processes, as well as to point out a significance of the beneficiation processes in order to increase the leaching efficiency of nickel and cobalt.

\section{Direct Nickel Process, Australia}

The Direct Nickel Process was developed in Australia representing a revolution in nickel production and a frontier advance in the processing of lateritic oxidic nickel ores (McCarthy \& Brock, 2011, pp. 2-11). The Direct Nickel Group from Australia has created a new, simple and efficient process for extracting nickel from oxidic ored from Indonesia, which will bridge the global nickel supply gap. Most steps in the verstaile flowsheet have been tested at a pilot scale. In 2007, a pre-feasibility study conducted independently by Kvaerner and studies by several independent experts confirmed its economic potential. The full process was demonstrated at a five tonnes a day scale. 


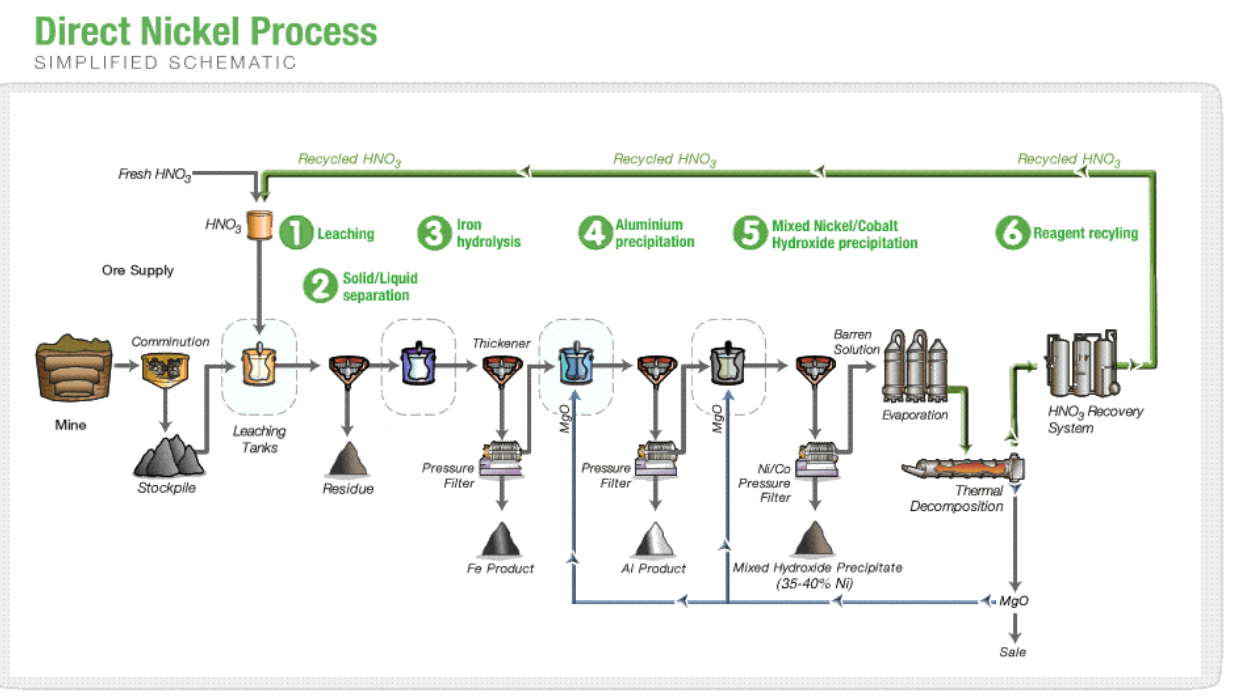

Figure 3-Flowchart of the Direct Nickel Process

Puc. 3 - Схема операций Direct Nickel Proces

Slika 3 - Pregled operacija u „Direct Nickel Procesu”

The DNi Process leach is operated at atmospheric pressure at $110^{\circ} \mathrm{C}$ in 304 stainless steel tanks at temperatures below the boiling point. Leaching takes between 2 and 4 hours.

2. Insoluble residue is separated from the pregnant leach solution (PLS), which now contains most of elements such as $\mathrm{Ni}, \mathrm{Co}, \mathrm{Fe}, \mathrm{Al}$ and Mg. The residue goes to a tailings disposal facility.

3. Iron Hydrolysis takes the pregnant leach solution and removes iron and chromium, making a hematite $\left(\mathrm{Fe}_{2} \mathrm{O}_{3}\right)$ product at temperatures about $170^{\circ} \mathrm{C}$. This is separated from the PLS by filtration at $50^{\circ} \mathrm{C}$.

4. Aluminium is precipitated in two steps by $\mathrm{MgO}$ addition and filtered from the solution in a form of white product- aluminium hydroxide.

5. A Mixed Hydroxide Product (MHP) is precipitated using $\mathrm{MgO}$ and filtered out of the solution. This MHP (40-45 wt.\% Ni, $2 \% \mathrm{Co})$ is the final product from the DNI.

6. The barren solution is passed through a series of evaporation vessels and then through thermal decomposition where magnesium nitrate converts to $\mathrm{MgO}$ and NOx gases. These gases are recycled back to nitric acid and reused in the leach circuit. Some of the produced $\mathrm{MgO}$ is recycled back to aluminium precipitation and mixed hydroxide precipitation, the remainder is available for sale as a high quality magnesia product.

The process is environmentally friendly because almost all the reagent is captured and recycled. The mass of waste residues is less than half that of HPAL processes due to minimal disposal of reagent and 
neutralization agents - and the production of saleable co-products. Valuable co-products are produced such as magnesium oxide. Maintenance costs are reduced by the low intensity of the process, and the simple materials of construction in comparison to titanium in an autoclave.

\section{Ravensthorpe Nickel Project, Australia}

Beneficiation is the process where a low-grade component of mineralization is separated from the rest and rejected, leaving a component with a higher grade to be treated in the leaching process. This is analogous to making a concentrate from a sulfide ore, but the concentration factor is much smaller for nickel laterite ores. A major difference between laterite (oxide) and nickel sulfide processing is that the sulfides ores are amenable to beneficiation producing high grade concentrates $(10$ to $26 \% \mathrm{Ni})$. This reduces both the size of the processing facilities (especially the front end processing facilities) and overall processing costs for sulfides. Only a limited upgrading (by a factor of $<3$, but mostly $<2$ ) can be carried out with laterite ores.

The combined Ravensthorpe Nickel Project RNP and Yabulu Refinery Expansion (BHP BILLITON 100\%) was a US\$ 1.4 billion project in regional Australia in 2004 that has produced high quality nickel metal and cobalt for global export markets. The Ravensthorpe orebody is distinctive in that it has a high silica content which enables the limonite ore to be upgraded to almost twice the mined grade through a beneficiation plant-a simple scrubbing and screening process to remove the barren hard silica (Adams, et al., 2004, pp.193-202).

The saprolite ore also upgrades but to a lesser extent. Limonite and saprolite are to be treated separately in two purpose-built beneficiation circuits, thereby increasing the nickel grade of the ore prior to leaching. The average grade of ore shipped from Berong has been greater than $1.5 \% \mathrm{Ni}$. The Ravensthorpe Nickel Project consists of 152 million tonne-resource of nickel laterite of the south coast of Western Australia. The project involves the mining and beneficiation of the nickel laterite ore, hydrometallurgical processing using Pressure Acid Leaching (PAL) technology and marketing of nickel and cobalt products. The project gives a PAL plant feed grade of $2.0 \% \mathrm{Ni}$, produces 25,000 tonnes per annum of LME grade nickel metal cathodes and 1,900 tonnes per annum of cobalt sulphide by-products. Screening and classification processes are used to separate out the finer higher grade fraction from the coarse grade fraction from the Run of Mine $\mathrm{ROM}$. The aim of the beneficiation circuit is to maximise $\mathrm{Ni}$ and Co recovery in the minimum weight fraction obtainable, while rejecting minerals containing quartz. The unit operations are: primary crushing, scrubbing, screening, cycloning, attritioning, classification, and thickening. 


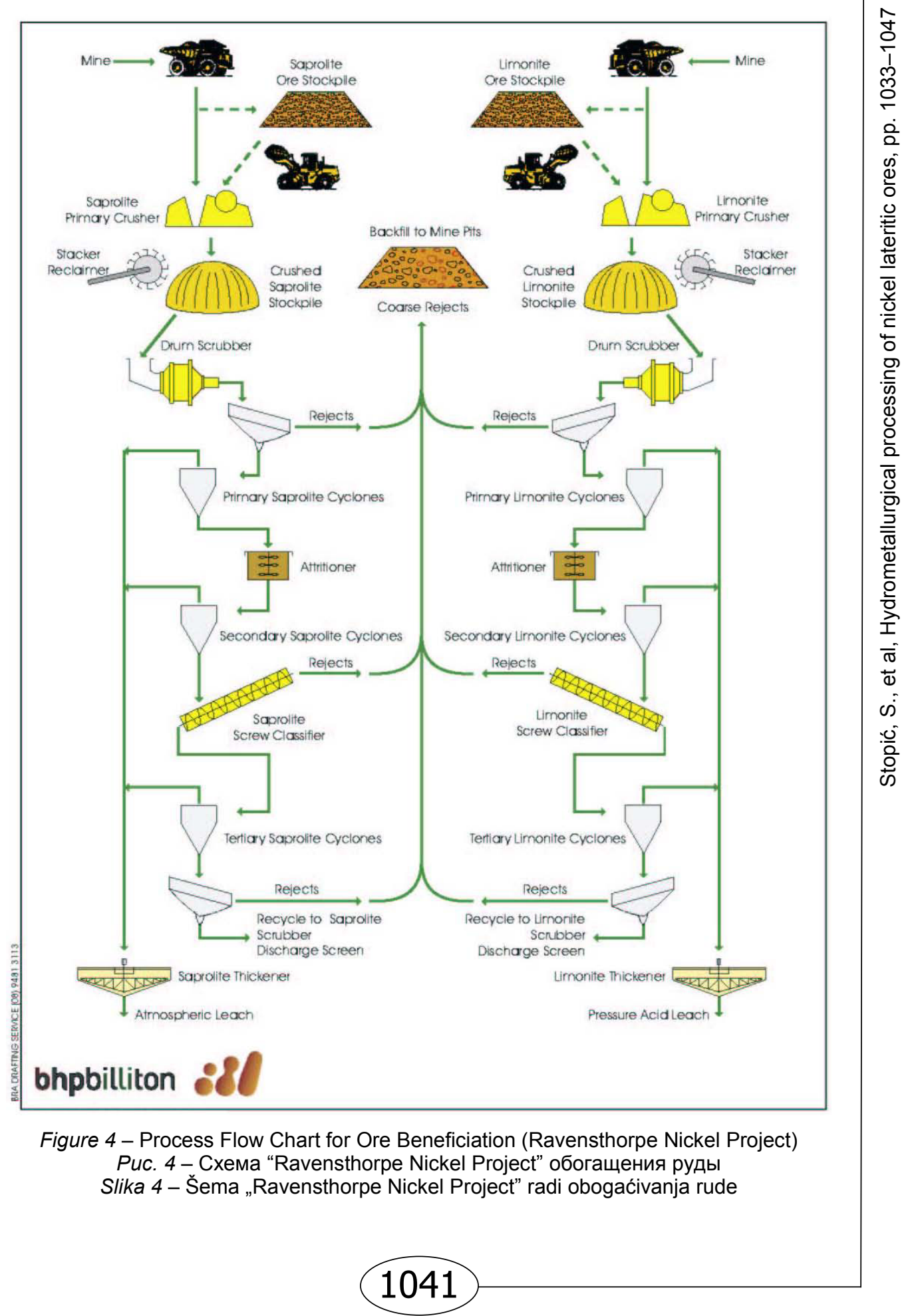




\section{Meta Nickel Cobalt Process, Turkey}

Meta Madencilik Ltd. Şti. was founded in 2000 by a group of professional engineers and it developed the Turkey's first nickel project. Meta has been carrying out the activities under the name of Meta Nikel Kobalt Madencilik Sanayi ve Ticaret A.Ş. since 2007. The Turkish "Meta" company is part of the "ZORLU Group", which is active in many different industries.

"Meta" has 3 project sites at which nickel and cobalt are extracted:

- Gordes nickel cobalt investment project

- Eskisehir nickel ore production \& exploration project

- Usak nickel exploration project

All plants extract metals from the lateritic ore. The previous investigation of nickel extraction from lateric ores was performed under atmospheric pressure (Büyükakıncı \& Topkaya, 2009, pp.33-38). The project area is located in Western Turkey, within the boundaries of Manisa Province, between Akhisar and Gördes Towns and around Fundacık - Çiçekli - Kabakoz and Kalemoğlu Villages. The mine site is $20 \mathrm{~km}$ away from the town of Gördes by an asphalt road and it is nearly $45 \mathrm{~km}$ from the town of Akhisar, $115 \mathrm{~km}$ from Manisa and $160 \mathrm{~km}$ from Izmir. The nearest state railway is about $40 \mathrm{~km}$ away.

A total of 230,000 tons of nickel ore has been produced from two open pits and 150,000 tons of ore have been exported to Greece, Macedonia and China since 2003. Approximately 80,000 tons of the remained nickel ore were stocked at the mine site, to be used during a trial production of the process plant, which is under construction. A world class laboratory was set up on the mine site in 2007, to conduct chemical analyses on the samples obtained from the exploration and drilling program. The following operations are used:

1) Ore Preparation $\rightarrow$ classification of ore particles

2) High Pressure Acid Leaching (HPAL) $\rightarrow$ leaching method to extract nickel and cobalt

3) Primary Iron Removal \& Re-Leach Area Solid Liquid Separation (CCD or SX)

4) Secondary Iron Removal (Secondary Neutralization)

5) MHP (Mixed Hydroxide Product) Precipitation-1

6) MHP (Mixed Hydroxide Product) Precipitation-2

7) Manganese Removal

8) Final Neutralization 


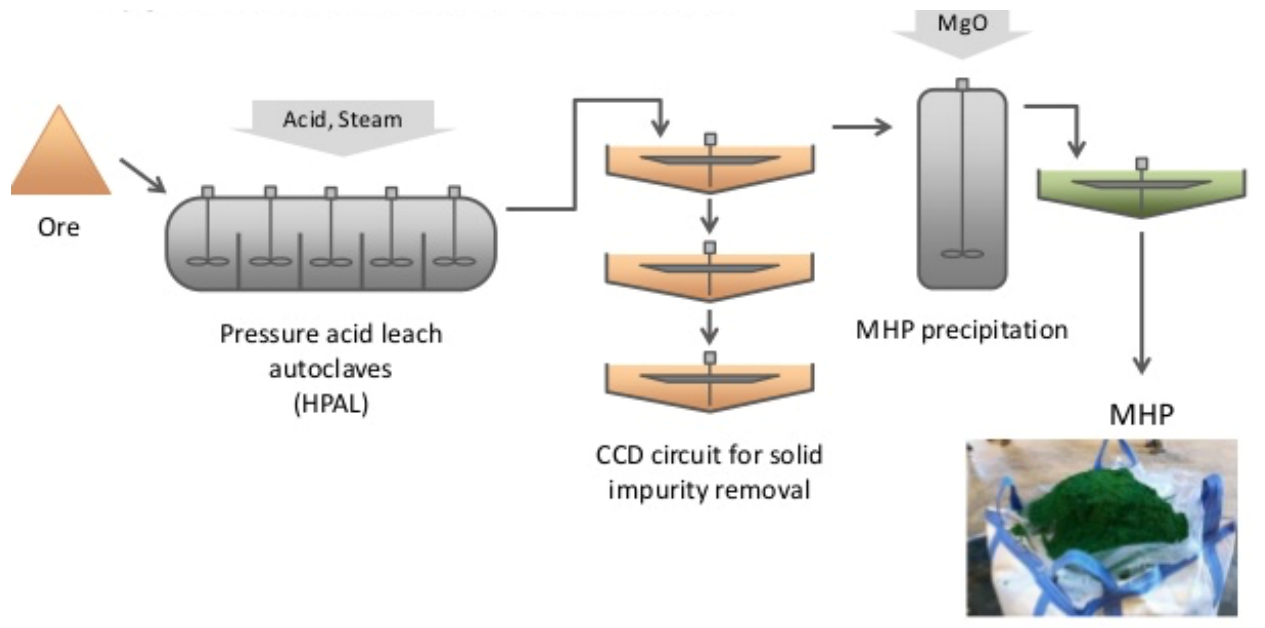

Figure 5 - Flowchart of the META Cobalt Nickel Process

Puc. 5- Схема META Cobalt Nickel Process

Slika 5 - Šema za „META Kobalt Nikal Process”

For the following neutralization, calcium carbonate is used. After that, nickel and cobalt are recovered from the solution in $98-99 \%$ yield by precipitation at $120{ }^{\circ} \mathrm{C}$ with hydrogen sulfide at a pressure of $1.1 \mathrm{MPa}$ in a three-compartment, brick-lined autoclave in accordance with the following reaction:

$$
\mathrm{NiSO}_{4}+\mathrm{H}_{2} \mathrm{~S} \rightarrow \mathrm{NiS}+\mathrm{H}_{2} \mathrm{SO}_{4}
$$

The final product has the following chemical composition of the mixed precipitate

Table 6 - Chemical composition of the final product Таблица 6 - Химический состав конечной продукции Tabela 6 - Hemijski sastav konačnog produkta

\begin{tabular}{|l|c|c|c|c|c|c|}
\hline$[\%]$ & $\mathrm{Ni}$ & $\mathrm{Co}$ & $\mathrm{Fe}$ & $\mathrm{Al}$ & $\mathrm{Mg}$ & $\mathrm{Mn}$ \\
\hline $\mathrm{MHP}-2$ & $30-40$ & $1.5-2$ & $<0.5$ & $1-2$ & 1.3 & 0.8 \\
\hline
\end{tabular}

The advantages of the META-process:

1) Capital expenditure and operational expenditure are relatively low

2) Sulphuric acid consumption is low

3) Reagent types and consumption is low

4) Metal extractions ( $\mathrm{Ni}$ and $\mathrm{Co}$ ) with respect to time are above $90 \%$ process:

The disadvantages of this process are related to the precipitation

1) Low Mg concentration necessary ( $<4 \%)$

2) Low Al concentration necessary (because Al is high acid consumer) 


\section{Murrin Murrin Project, Australia}

Minara is the fully integrated nickel laterite producer in the world. The Murrin Murrin nickel-cobalt project, $60 \mathrm{~km}$ east of Leonora, was commissioned by Anaconda Nickel Ltd. The project is now a joint venture between Murrin Murrin Holdings Pty Ltd, a wholly owned subsidiary of Minara Resources Ltd (60\%), and Glenmurrin Pty Ltd, a wholly owned subsidiary of Glencore International AG (40\%). It is based on the mining and processing of lateritic ore for the production of up to 40,000t/y of nickel and $2,500 t / y$ of cobalt briquettes. After mining from the nearby open pits, the ore is delivered to the run of mine (ROM) pad, where it is sorted depending on its grade and blended to ensure consistent feed to the feed preparation circuit. The ore is then mixed with water to form slurry for processing in the High Pressure Acid Leach (HPAL) circuit. (four titanium autoclaves in a line).

The most important operations in the Murrin Murrin process contain:

1. mining and rehabilitation

2. ore preparation

3. High Pressure Acid Leach (HPAL)

4. solid/liquid separation-counter current decantation

5. solution neutralization

6. mixed sulfide precipitation

7. tailling neutralization

8. oxygen pre-leach of nickel and cobalt values

9. nickel and cobalt separation

10. nickel and cobalt refining

11. metal package

Mr. Johnston from Minara Resources reported he had finally laid the ghosts of the company's troubled past to bed, nearly 14 years after the first nickel was produced at its Murrin Murrin mine (Evans, 2013, pp.63). Murrin Murrin produces nickel and cobalt briquettes that easily meet the highest grade standards of the London Metals Exchange and are highly regarded and in strong demand from consumers around the world (http://www.minara.com.au/about/operations-overview/technology).

\section{Conclusion}

Hydrochloric, nitric and sulphuric acids were successfully used for the leaching of laterite ores. The dissolution kinetics of lateritic ores in an acidic solution of three metabolic acids confirmed low leaching efficiency of nickel and cobalt. Tank leaching, heap leaching and high pressure acidic leaching are mostly used for the hydrometallurgical treatment of lateritic ores. The Direct Nickel Proces, the Meta Cobalt Nickel Process 
and the Murrin Murrin Process show a high potential for the production of nickel and cobalt. The application of HPAL for laterites is expected to continue - especially for large projects and high grade deposits. Regarding lower grade deposits, further development of the heap leaching process for small projects is expected. The beneficiation process of laterite ores was successfully performed in the Ravensthorpe plant in Australia in order to produce a nickel concentrate. Finally, nickel and cobalt have become essential materials in modern life.

\section{References}

Adams, M., \& et al., 2004. Piloting of the Beneficiation and EPAL Circuits for Ravensthorpe Nickel Operations. In: W. Imrie\& et al. Eds., International Laterite Nickel Symposium, pp.193-202

Bergman, R. 2003. Nickel Production from low-iron Laterite Ores: Process description. CIM Bulletin, 96, pp.127-138.

Büyükakıncı, E., \& Topkaya, Y.A. 2009. Extraction of Nickel from Lateritic Ores at Atmospheric Pressure with Agitation Leaching. Hydrometallurgy, 97, pp.33-38.

Dry, M., \& Haris.B., 2012. Nickel laterite and three mineral acids . In: ALTA Nickel and Cobalt conference, pp.20-35

Evans, N. 2013. Minara finally puts troubled Murrin Murrin past to bed, The West Australian, p.63.

McCarthy, F. \& Brock, G. 2011. The Direct Nickel Process: Continued Progress on the Pathway to Commercialisation. In: ALTA Conference, pp.2-11

Sahu, S., Kavuri, N., \& Kundu, M. 2011. Dissolution Kinetics of Nickel laterite ore using different secondary metabolic acids.Brazilian Journal of Chemical Engineering, 258, p.251.

Stopic, S., \& Friedrich, B. 2011. Pressure Hydrometallurgy: A new chance for nonpolluting processes. Vojnotehnicki glasnik / Military Technical Courier, 59(3), pp.29-44.

Stopić, S., Friedrich, B., Fuchs, R., \& Anastasijevic, N. 2004. Kinetics of high pressure leaching of nickel lateritic ores "Silcrete". Acta Metallurgica Slovaca, 2, pp.257-266.

Superiadi, A. 2008. Processing Technology vs Nickel Laterite Ore Characteristic. Retrieved from

http://www.powershow.com/view1/1b35aa-ZDc1Z/Processing_Technology_vs_Ni/

Whittington, B. \& Muir, D. 2000. Pressure Acid Leaching of Nickel Laterites: A Review. Min. Pro. Ext. Mat. Rev., 21, pp.527-600.

Retrieved from http://www.minara.com.au/about/operations-overview/technology.

\section{ГИДРОМЕТАЛЛУРГИЧЕСКАЯ ОБРАБОТКА ЛАТЕРИТНЫХ} РУД НИКЕЛЯ

Сречко Р. Стопич, Бернд Г. Фридрих

Технический университет города Ахен, Институт металлургических процессов и рециклирования металлов, Германия

ОБЛАСТЬ: химические технологии

ВИД СТАТЬИ: обзорная статья

ЯЗЫК СТАТЬИ: английский 
Резюме:

Производство никеля представляет важную отрасль промышленности в Евросоюзе, так как никель является составляющим элементом в производстве нержавеющей стали. Европа обладает ресурсами оксидных руд, находящихся на большой территории от Альп до Гималаев, охватывая западную часть Балкан и Грецию, простилаясь через Турцию до Азии. Известные резервы латеритных руд находятся в Сербии, располагаясь в трех зонах: Западная Морава (Руждинцы, Велуце, Ба), Шумадия (Липовац, Коларевичи, Бучье) и Мокра Гора, представляющих собой природные ресурсы, такие как: лес, реки и пр. Очень важно понимать и оценить применение латеритных руд в области горной промышленности и металлургии в разных частях мира. В данной статье представлено несколько эксплуатационных сценариев латеритных руд в области гидрометаллургии: Direct Nickel Process, Murrin Murrin u Ravensthorpe в Австралии, и META Process в Tурции.

Ключевые слова: никель, кобальт, латеритные руды, гидрометаллургия, автоклав.

\section{HIDROMETALURŠKO TRETIRANJE LATERITNIH RUDA NIKLA}

Srećko R. Stopić, Bernd G. Friedrich

Institut za procesnu metalurgiju i recikliranje metala,

Tehnički univerzitet u Ahenu, Nemačka

OBLAST: hemijske tehnologije

VRSTA ČLANKA: pregledni članak

JEZIK ČLANKA: engleski

\section{Sažetak:}

Proizvodnja nikla je vrlo značajna aktivnost u zemljama Evropske unije, jer nikal je važan dodatak u nerđajućim čelicima. Evropa ima resurse oksidnih ruda duž dobro poznatog prostora koji započinje od Alpa i završava se na Himalajima. Ovaj opasač prolazi kroz zapadni Balkan i Grčku i nastavlja se kroz Tursku do Azije. Poznati depoziti lateritnih ruda u Srbiji smešteni su u tri zone: Zapadnoj Moravi (Ruđinci, Veluce, Ba), Šumadiji (Lipovac, Kolarevići, Bučje) i Mokroj gori, koje predstavljaju prirodne resurse, kao što su šume i reke. Lateritna ruda tretira se u rudarstvu i metalurgiji u raznim područjima sveta. U ovom radu biće predstavljeno nekoliko eksploatacionih scenarija preko hidrometalurškog tretiranja: „Direct Nickel Process”, „Murrin Murrin” i „Ravensthorpe" u Australiji, i „META Process” u Turskoj.

Ključne reči: nikal, kobalt, lateritne rude, hidrometalurgija, autoklav. 
Paper received on / Дата получения работы / Datum prijema članka: 28. 03. 2016. Manuscript corrections submitted on / Дата получения исправленной версии работы / Datum dostavljanja ispravki rukopisa: 27. 05. 2016.

Paper accepted for publishing on / Дата окончательного согласования работы / Datum konačnog prihvatanja članka za objavljivanje: 28. 05. 2016.

(C) 2016 The Authors. Published by Vojnotehnički glasnik / Military Technical Courier (www.vtg.mod.gov.rs, втг.мо.упр.срб). This article is an open access article distributed under the terms and conditions of the Creative Commons Attribution license (http://creativecommons.org/licenses/by/3.0/rs/).

( 2016 Авторы. Опубликовано в "Военно-технический вестник / Vojnotehnički glasnik / Military Technical Courier" (www.vtg.mod.gov.rs, втг.мо.упр.срб). Данная статья в открытом доступе и распространяется в соответствии с лицензией "Creative Commons" (http://creativecommons.org/licenses/by/3.0/rs/).

(c) 2016 Autori. Objavio Vojnotehnički glasnik / Military Technical Courier (www.vtg.mod.gov.rs, втг.мо.упр.срб). Ovo je članak otvorenog pristupa i distribuira se u skladu sa Creative Commons licencom (http://creativecommons.org/licenses/by/3.0/rs/). 